\title{
MAUSU'AH WA MAFHUMUL HADIS LARANGAN TRANSAKSI RIBA DALAM MUSNAD AHMAD
}

\author{
Nurhadi \\ STAl al-Azhar Pekanbaru \\ alhadicentre@yahoo.co.id
}

\begin{abstract}
Islam is a comprehensive religion that encapsulates all human life including economic activities. This era of modern and sophisticated times, the phenomenon of the development of existing business activities must be vigilant, so as not to fall prey to usury. Then what about the hadith in Ahmad's musnad relating to usury ?. The results of the author's research in the book mausu'ah al-hadis al-Nabawiyah, from the hadith perspective in the book Musnad Ahmad. Then found 6 traditions related to usury property. The hadith is No. Hadith 803 in the Book: Musnad of ten companions guaranteed to enter heaven, Chapter: Musnad Ali bin Abu Talib Radliyallahu 'anhu. Hadith No. 1222 in the Book: Musnad of ten companions who are guaranteed to enter heaven, Chapter: Musnad Ali bin Abu Talib Radliyallahu 'anhu. Hadith No. 1294 in the Book: Musnad of ten companions guaranteed to enter heaven, Chapter: Musnad Ali bin Abu Talib Radliyallahu 'anhu. Hadith No. 3539 in the Book: Musnad companions who have narrated many hadith, Chapter: Musnad Abdullah bin Mas'ud Radliyallahu ta'ala 'anhu. Hadith No. 3567 in the Book: Musnad friends who have narrated many hadith, Chapter: Musnad Abdullah bin Mas'ud Radliyallahu ta'ala 'anhu. Hadith No. 13744 in Ahmad Musnad, it will appear in the Book: Remaining Musnad companions who have narrated many hadith, Chapter: Musnad Jabir bin Abdullah Radliallahu ta'ala 'anhu. So from the hadith it can be drawn the understanding that Allah cursed the eaters of usury, the person who gave food with usury, the witness of the usury contract and the person who wrote it. Even though a lot of usury will eventually be a little.
\end{abstract}

Keywords : Mausu'ah, Mafhum, Hadith, Prohibition, Usury Transaction.

\section{Pendahuluan}

Islam adalah agama yang komprehensif yang merangkum seluruh kehidupan manusia termasuk kegiatan ekonomi. Pelaksanaan Islam secara menyeluruh akan membawa rahmat kepada sekalian alam termasuk manusia yang menjalankan kegiatan ekonomi (Boy Syamsul Bakhri, 2011: 48-49). Era zaman modern dan serba canggih ini perkembangan sistem ekonomi sudah sangat pesat. Beragam sistem ditawarkan oleh para pembisnis

untuk bersaing menggaet hati para pelanggan. Seorang ekonomi muslim yang tidak hanya berorientasi pada keuntungan dunia saja,sudah semestinya harus cerdik,juga senantiasa menganalisa fenomena perkembangan kegiatan bisnis yang ada, supaya mengetahui pandangan syariat terhadap suatu transaksi bisnis,sehingga tidak mudah terje- 
rumus ke dalam larangan-Nya (riba) (Muslim, https://muslim.or.id, 2018).

Kegiatan ekonomi bisnis yang sangat di gemari kebanyakan masyarakat adalah jual beli kredit. Salah satu transaksi yang cepat mendapatkan barang dan keuntungan adalah jual beli kredit. Diantara akad jual beli yang dilarang dengan pelanggaran yang keras antara lain adalah Riba. Dalam Islam, memungut riba atau mendapatkan keuntungan berupa riba pinjaman adalah haram. Ini dipertegas dalam al-Qur'an Surah al-Baqarah ayat 275 :

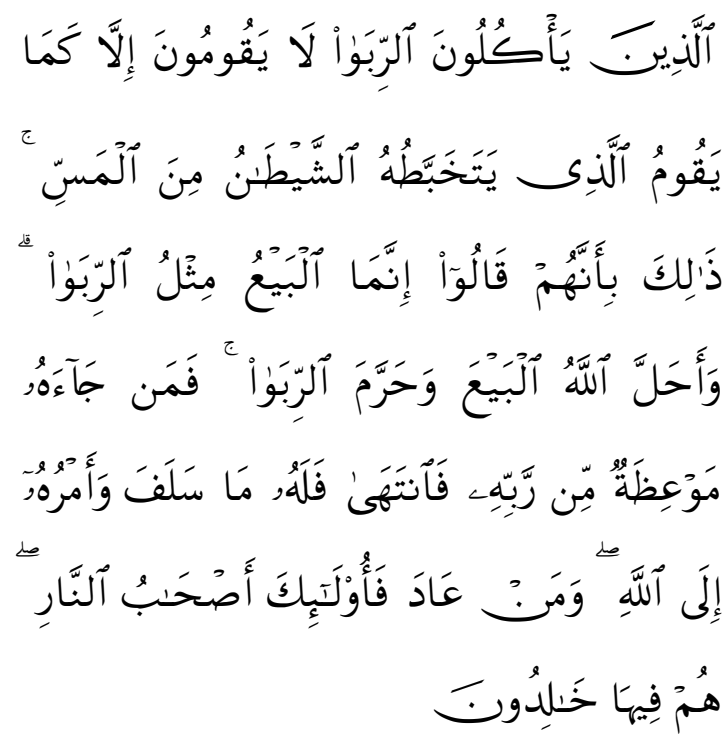

Artinya: Orang-orang yang makan (mengambil) riba (Riba itu ada dua macam: nasiah dan fadhl. riba nasiah ialah pembayaran lebih yang disyaratkan oleh orang yang meminjamkan. riba fadhl ialah penukaran suatu barang dengan barang yang sejenis, tetapi lebih banyak jumlahnya Karena orang yang menukarkan mensyaratkan demikian, seperti penukaran emas dengan emas, padi dengan padi, dan sebagainya. riba yang dimaksud dalam ayat Ini riba nasiah yang berlipat ganda yang umum terjadi dalam masyarakat Arab zaman Jahiliyah) tidak dapat berdiri melainkan seperti berdirinya orang yang kemasukan syaitan lantaran (tekanan) penyakit gila (maksudnya: orang yang mengambil riba tidak tenteram jiwanya seperti orang kemasukan syaitan.). keadaan mereka yang demikian itu, adalah disebabkan mereka Berkata (berpendapat), Sesungguhnya jual beli itu sama dengan riba, padahal Allah Telah menghalalkan jual beli dan mengharamkan riba. orangorang yang Telah sampai kepadanya larangan dari Tuhannya, lalu terus berhenti (dari mengambil riba), Maka baginya apa yang Telah diambilnya dahulu (riba yang sudah diambil (dipungut) sebelum turun ayat ini, boleh tidak dikembalikan) (sebelum datang larangan); dan urusannya (terserah) kepada Allah. orang yang kembali (mengambil riba), Maka orang itu adalah penghuni-penghuni neraka; mereka kekal di dalamnya (Departemen Agama, 2015: 69).

Selain firman allah swt diatas, juga menjadi dalil tentang riba, terdapat dalam surah al-Imran ayat 130 sebagai berikut:

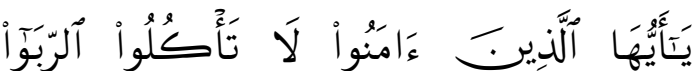

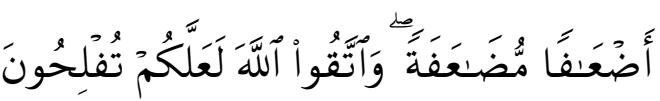

Artinya: Hai orang-orang yang beriman, janganlah kamu memakan riba dengan berlipat ganda (yang dimaksud riba di sini ialah riba nasi'ah. menurut sebagian besar ulama bahwa riba nasi'ah itu selamanya Haram, walaupun tidak berlipat ganda. Riba itu ada dua macam: nasiah dan fadhl. riba nasiah ialah pembayaran lebih yang disyaratkan oleh orang yang meminjamkan. riba fadhl ialah penukaran suatu barang dengan barang yang sejenis, tetapi 
Nurhadi : Mausu'ah Wa Mafhumul Hadis Larangan Transaksi Riba Dalam Musnad Ahmad

lebih banyak jumlahnya Karena orang yang menukarkan mensyaratkan demikian, seperti penukaran emas dengan emas, padi dengan padi, dan sebagainya. riba yang dimaksud dalam ayat Ini riba nasiah yang berlipat ganda yang umum terjadi dalam masyarakat Arab zaman Jahiliyah) dan bertakwalah kamu kepada Allah supaya kamu mendapat keberuntungan (Departemen Agama, 2015: 97). Dalam surah al-Baqarah ayat 276 sebagai berikut:

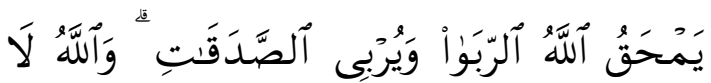

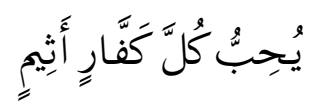

Artinya: Allah memusnahkan riba dan menyuburkan sedekah (yang dimaksud dengan memusnahkan riba ialah memusnahkan harta itu atau meniadakan berkahnya. dan yang dimaksud dengan menyuburkan sedekah ialah memperkembangkan harta yang Telah dikeluarkan sedekahnya atau melipat gandakan berkahnya). dan Allah tidak menyukai setiap orang yang tetap dalam kekafiran, dan selalu berbuat dosa (maksudnya ialah orang-orang yang menghalalkan riba dan tetap melakukannya) (Departemen Agama, 2015: 69). Dalam surah al-Baqarah ayat $278-279$ sebagai berikut:
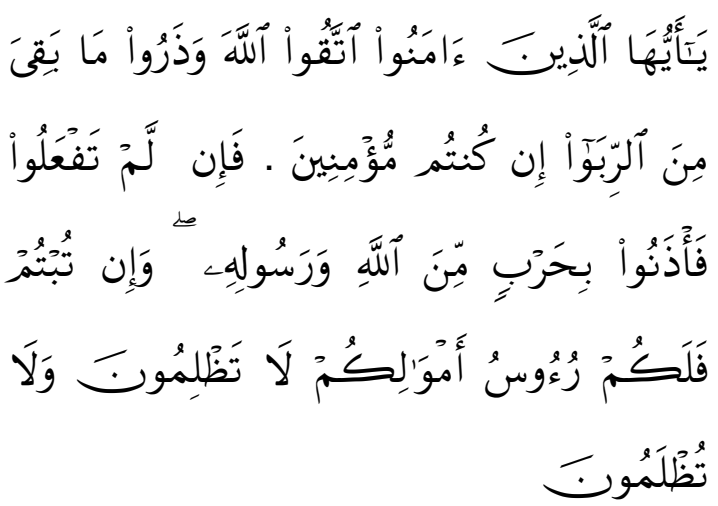

Artinya: Hai orang-orang yang beriman, bertakwalah kepada Allah dan tinggalkan sisa riba (yang belum dipungut) jika kamu orang-orang yang beriman. Maka jika kamu tidak mengerjakan (meninggalkan sisa riba), Maka Ketahuilah, bahwa Allah dan rasul-Nya akan memerangimu. dan jika kamu bertaubat (dari pengambilan riba), Maka bagimu pokok hartamu; kamu tidak menganiaya dan tidak (pula) dianiaya (Departemen Agama, 2015: 69-70).

Dan di antara hadis yang terkait dengan riba adalah :

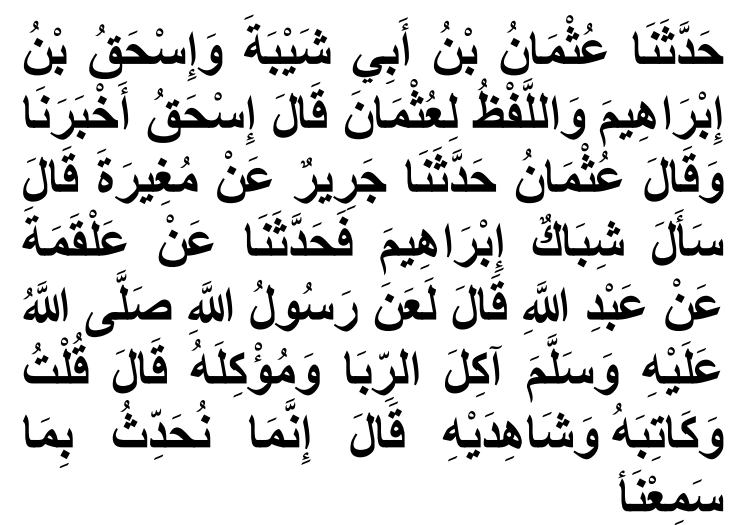

Artinya: Telah menceritakan kepada kami Utsman bin Abu Syaibah dan Ishaq bin Ibrahim dan ini adalah lafadz Utsman. Ishaq berkata; telah mengabarkan kepada kami, dan Utsman berkata; telah menceritakan kepada kami Jarir dari Mughirah dia berkata, "Syibak bertanya kepada Ibrahim, lalu ia menceritakan kepada kami dari 'Alqamah dari Abdullah dia berkata, "Rasulullah shallallahu 'alaihi wasallam melaknat orang yang memakan hasil riba dan yang menyuruh memakannya." 'Alqamah berkata, "Saya bertanya, "(Bagaimana dengan) sekretaris pembuat akte riba dan saksisaksinya?" dia menjawab, "Kami hanya menceritakan dari sesuatu yang kami dengar." (HR. Muslim No. 2994).

Melalui ayat dan hadis diatas, agar secara detail hadis-hadis tentang riba dalam shahih bukhari yang menjadi rujukan utama setelah 
al-qur'an. Maka dalam tulisan penelitian ini akan membahas teks nash hadis Nabi saw dalam masalah riba dalam kitab hadis shahih bukhari.

\section{KERANGKA TEORI Biografi Imam Ahmad bin Hambal}

Ahmad bin Muhammad ibn Hanbal al-Syaibany dilahirkan di Baghdad tepatnya di Kota Maru/Merv, pada bulan Rabi'ul awal tahun $164 \mathrm{H}$ atau Nopember 780 M. nama lengkapnya ialah Ahmad ibn Muhammad ibn Hanbal ibn Hilal ibn Asad ibn Idris abn 'Abdillah bin Hayyan ibn 'Bdillah bin Anas ibn 'Awf ibn Qasit bin Mazin ibn Syaiban ibn Zual ibn Ismail ibn Ibrahim (Ibnu Jauzi, t.th: 420; Ibnu Jauzi, t.th: 177358; Ibnu Kasir, t.th: 325-342).

Ketika Ahmad masih kecil, ayahnya berpulang kepada Allah swt dengan hanya meninggalkan harta pas-pasan untuk menghidupi keluarganya. Sebuah riwayat menyebutkan bahwa, jika Ahmad ibn Hanbal ditanya mengenai asal-usul sukunya, dia mengatakan bahwa ia adalah anak dari suku orang-orang miskin. Dia hidup sebagaimana layaknya rakyat jelata, tinggal di tengah-tengah mereka dan merasakan penderitaan, luka san duka cita mereka (Ziaul Haque, terj. Nurul Agustina, 2012: 96). Kondisi yang demikian menjadi salah satu pendorong bagi Ahmad untuk belajar dengan sungguh-sunghuh. Dia ingin seggera bisa mengurangi beban ibunya. Dia juga melihat banyaknya bid'ah yang tersebar di masyarakat. Hal itu pula lah yang mendorong dia untuk pergi ke berbagai wilayah mencari hadis (Musthafa Hamdu Ullayan al-Hambali, 2018: 18).

Ahmad menikah dan memiliki dua orang putra yang terkenal dalam bidang hadis yaitu Salih dan Abdullah.
Kedua puteranya banyak menerima hadis dari sang ayah dan memasukkan sejumlah hadis ke dalam kitab Musnad ayahnya. Imam Ahmad ibn Hanbal adalah gambaran seorang tokoh yang sederhana, merakyat dan mempunyai komitmen keislaman tinggi. Kecintaan beliau pada hadis dan kesetiaan pada Nabi yang harus dibayar dengan pengorbanan fisik dan non fisik, merupakan satu nilai tambah yang harus dihargai (Musthafa Hamdu Ullayan al-Hambali: 19).

Pada tahun $195 \mathrm{H}$ sampai 197 $\mathrm{H}$ Ahmad belajar fiqh dan Ushul Fiqh pada Imam Syafi'i yang pada waktu itu berada di hijaz. Di Hijaz pula ia belajar pada Imam Malik dan Imam al-Laitsbin Sa'ad al-Misri. Dalam pencarian hadis ia juga pergi ke Yaman dan ke daerah-daerah lain, seperti Khurasan, Persia, dan Tarsus (Musthafa Hamdu Ullayan al-Hambali: 20).

Sebuah kitab dinamakan kitab Musnad apabila penyusunnya memasukkan semua hadis yang pernah dia terima, dengan tanpa menyaring dan menerangkan derajat hadis-hadis tersebut (Hasbi AlShiddieqy, 2015: 104). Pengertian lain dari kitab Musnad ialah kitab yang hadis-hadis di dalamnya disebutkan berdassarkan nama sahabat yang lebih dahulu masuk islam atau berdasarkan nasa'b. Dilihat dari nilai hadis yang ada di dalam kitab, menurut ulama, derajat kitab ini berada di bawah kitab Sunan. Subhi al-Salih menempatkan Musnad Ahmad pada peringkat kedua yang sederajat dengan Jami' al-Tarmizi dan Sunan Abu Dawud (Hasbi AlShiddieqy, 2015: 104).

Musnad Ahmad termasuk termasuk kitab termashur dan terbesar yang disusun pada periode 
kelima perkembangan hadis. Kitab ini melengkapi dan menghimpun kitabkitab hadis yang ada sebelumnya dan merupakan satu kitab yang dapat memenuhi kebutuhan muslim dalam hal agama dan dunia pada masanya. Hadis-hadis yang terdapat dalam Musnad terdebut tidak semua riwayat Ahmad, sebagian merupakan tambahan dari puteranya yang bernama Abdullah dan tambahan dari Abu Bakar al-Qati'i (Musthafa Hamdu Ullayan al-Hambali: 31). Musnad tersebut memuat 40.000 hadis. Tambahan dari Abdullah sekitar 10.000 hadis dan beberapa tambahan pula dari Ahmad bin Ja'far al-Qatili. Abdullah ibn Ahmad ibn Hanballah yang menyusun Kitab Musnad ini (Musthafa Hamdu Ullayan al-Hambali: 31).

\section{Konsep Riba Dalam Islam}

Pada dasarnya transaksi riba dapat terjadi dari transaksi hutang piutang, namun bentuk dari sumber tersebut bisa berupa qard, Qard berasal dari kata قضضر يقرض قرض yang berarti pinjaman (Ahmad Munawir, 2010: 1108), menurut Abdurrahman al-Jaziri, qard adalah harta yang diambil oleh orang yang meminjam karena orang yang meminjam tersebut memotong dari harta miliknya (Abdurrahman al-Jaziri, 2012: 338), buyu', Menurut Abdullah al-Mushlih dan Shalah ash-Shawi jual beli adalah dua kata yang saling berlawanan artinya, namun masingmasing sering digunakan untuk arti kata yang lain secara bergantian. Oleh sebab itu, masing-masing dalam akad transaksi disebut sebagai pembeli dan penjual. Rasulullah saw. Bersabda, "dua orang yang berjual beli memiliki hak untuk menentukan pilihan, sebelum mereka berpindah dari lokasi jual beli." Akan tetapi bila disebutkan secara umum, yang terbetik dalam hak adalah bahwa kata penjual diperuntukan kepada orang yang mengeluarkan barang dagangan. Sementara pembeli adalah orang yang mengeluarkan bayaran. Penjual adalah yang mengeluarkan barang miliknya. Sementara pembeli adalah orang yang menjadikan barang itu miliknya dengan kondisi kompensasi pembayaran (Abdullah al-Mushlih, el, 2014: 89-90). Menurut Chairuman Pasaribu dan Suhrawardi K. Lubis: Kata Jual beli terdiri dari dua suku kata yaitu jual dan beli. Sebenarnya kata "jual" dan "beli" mempunyai arti satu sama lainnya bertolak belakang dan lain sebagainya (Chairuman Pasaribu, el. 2014: 33).

Para ulama menetapkan dengan tegas dan jelas tentang pelarangan riba, disebabkan riba mengandung unsur eksploitasi yang dampaknya merugikan orang lain, hal ini mengacu pada Kitabullah dan Sunnah Rasul serta ijma' para ulama. Bahkan dapat dikatakan tentang pelarangannya sudah menjadi aksioma dalam ajaran Islam (Abdullah al-Mushlih, el: 345). Kata riba berasal dari bahasa Arab, secara etimologis berarti tambahan (alziyadah) (Abu Sura'i Abdul Hadi, 2013: 125), berkembang (an-numuw), membesar (al-'uluw), menurut Syaikh Abul A'la al-Maududi An-Numuw adalah pertumbuhan dan Al-'Uluw adalah tinggi. dan meningkat (al-irtifa) (Syaikh Abul A'la al-Maududi, 2014: 110).

Sehubungan dengan arti riba dari segi bahasa tersebut, ada ungkapan orang Arab kuno menyatakan sebagai berikut; arba fulan 'ala fulan idza azada 'alaihi (seorang melakukan riba terhadap orang lain jika di dalamnya terdapat 
unsur tambahan atau disebut liyarbu ma a'thaythum min syai'in lita'khuzu aktsara minhu (mengambil dari sesuatu yang kamu berikan dengan cara berlebih dari apa yang diberikan) (Khoiruddin, 2006: 37).

\section{METODOLOGI}

Jenis penelitian ini adalah termasuk penelitian kualitatif, karena sifat data yang akan dikumpulkan bercorak kualitatif (Lexy J Moleong, 2011: 11; Imam Suprayogo, el, 2012: 9; Bungin Burhan, 2014: 31). Oleh karena itu data penelitian bersifat naturalis dengan memakai logika induktif dan pelaporannya bersifat deskriptif (Hadari Nawawi, 2016: 67; Dedy Mulyana, 2015: 27). Penelitian ini terfokus pada penelitian kepustakaan (library research) atau studi teks (Iskandar, 2010: 29; HB Sutopo, 2014: 17). Maka penelitian ini akan lebih memusatkan perhatian pada pengkajian-pengkajian terhadap teks, dan termasuk jenis penelitian kualitatif (Hamidi, 2014: 13; Neong Muhajir, 2017: 17).

$$
\text { Penelitian }
$$

kepustakaan dilakukan karena sumber-sumber datanya, baik yang utama (primary resources) maupun pendukung (secondary resources) seluruhnya adalah teks (Muhammad Nazir, 2015: 58; Sugiyono, 2016: 21). Dalam hal ini sumbernya adalah kitab mausu'ah al-Hadis al-Nabawiyah dan tematiknya (al-Mausu'ah digital sofwer).

\section{PEMBAHASAN}

Penelitian penulis dalam kitab mausu'ah al-hadis al-Nabawiyah, dari persepktif hadis dalam Musnad Ahmad. Maka dapat ditemukan hadis berkaitan dengan riba sebanyak 6 hadis dalam kitab tersebut, dimulai dari hadis nomor $803 \mathrm{~s} / \mathrm{d} 13744$. Lihat tabel mausu'ahnya sebagai berikut:

\begin{tabular}{|c|c|c|c|}
\hline zo & 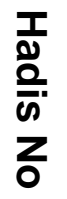 & $\begin{array}{l}\text { Judul } \\
\text { dalam } \\
\text { Kitab } \\
\text { Hadis }\end{array}$ & $\begin{array}{ll}\text { Teks } & \text { Naskah } \\
\text { Arab Kitab } & \text { Hadis }\end{array}$ \\
\hline 1 & $\begin{array}{l}\infty \\
\text { Oे } \\
\text {. }\end{array}$ & $\begin{array}{l}\text { Musnad Ali } \\
\text { bin Abu } \\
\text { Thalib } \\
\text { Radliyallah } \\
\text { u 'anhu }\end{array}$ & 9 \\
\hline 2 & $\vec{N}$ & $\begin{array}{l}\text { Musnad Ali } \\
\text { bin Abu } \\
\text { Thalib } \\
\text { Radliyallah } \\
\text { u 'anhu }\end{array}$ & \\
\hline 3 & $\overrightarrow{\mathscr{N}}$ & $\begin{array}{l}\text { Musnad Ali } \\
\text { bin Abu } \\
\text { Thalib } \\
\text { Radliyallah } \\
\text { u 'anhu }\end{array}$ & \\
\hline 4 & $\begin{array}{l}\text { 心్ } \\
\text { W్ }\end{array}$ & $\begin{array}{l}\text { Musnad } \\
\text { Abdullah } \\
\text { bin Mas'ud } \\
\text { Radliyallah } \\
\text { u ta'ala } \\
\text { 'anhu }\end{array}$ & نه \\
\hline 5 & $\begin{array}{l}\text { w } \\
\text { J్ }\end{array}$ & $\begin{array}{l}\text { Musnad } \\
\text { Abdullah } \\
\text { bin Mas'ud } \\
\text { Radliyallah } \\
\text { u ta'ala } \\
\text { 'anhu }\end{array}$ & عنبد الله \\
\hline 6 & $\begin{array}{l}\vec{J} \\
\stackrel{\vec{D}}{+}\end{array}$ & $\begin{array}{l}\text { Musnad } \\
\text { Jabir bin } \\
\text { Abdullah } \\
\text { Radliyallah } \\
\text { u ta'ala } \\
\text { 'anhu }\end{array}$ & غني \\
\hline
\end{tabular}


Nurhadi : Mausu'ah Wa Mafhumul Hadis Larangan Transaksi Riba Dalam Musnad

Jika dilihat dari hadis 803 dalam kitab musnad ahmad, maka akan muncul pada Kitab: Musnad sepuluh sahabat yang dijamin masuk surga, Bab: Musnad Ali bin Abu Thalib Radliyallahu 'anhu, No. Hadist: 803, hadisnya sebagai berikut:

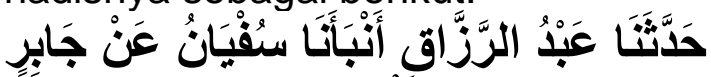

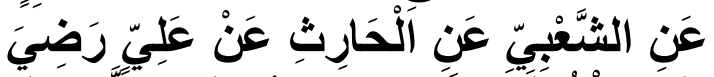

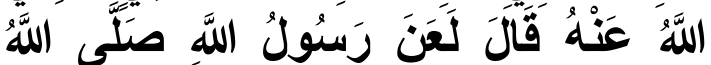

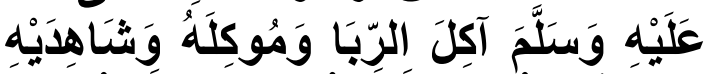

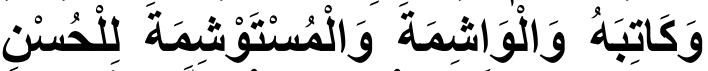

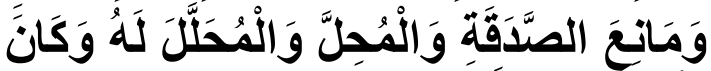

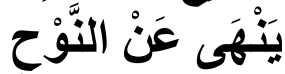

Artinya: Telah mengabarkan kepada kami Abdurrazzaq telah memberitakan kepada kami Sufyan dari Jabir dari Asy Sya'bi dari Al Harits dari Ali Radliallah 'anhu, dia berkata; "Rasulullah shallallahu 'alaihi wasallam melaknat orang yang memakan riba, orang yang memberi makan dengan harta riba, kedua saksinya, orang yang mentato dan orang meminta ditato agar kelihatan bagus, orang yang tidak mau membayar zakat, al muhil dan al muhallal lahu, dan beliau juga melarang meratapi mayat." (HR Ahmad, t.th: No. 803).

Hadis Ahmad No. 803 diatas didukung dengan 22 hadis dari beberapa riwayat. Lihat tabel mausu'ah hadis kutub al-Tis'ah berikut ini:

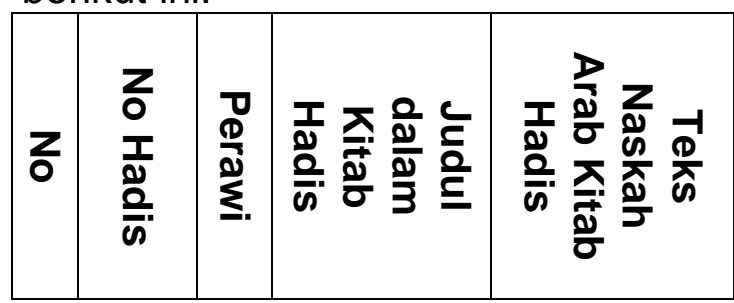

\begin{tabular}{|c|c|c|c|c|}
\hline 1 & 2994 & $\frac{\frac{3}{c}}{\frac{0}{5}}$ & $\begin{array}{l}\text { Pemakan } \\
\text { riba dan } \\
\text { pemberiny } \\
\text { a akan } \\
\text { dilaknat }\end{array}$ & لعن آلربا ومؤكله \\
\hline 2 & 2995 & $\frac{\frac{3}{\frac{1}{0}}}{\frac{5}{3}}$ & $\begin{array}{l}\text { Pemakan } \\
\text { riba dan } \\
\text { pemberiny } \\
\text { a akan } \\
\text { dilaknat }\end{array}$ & لالربا ومؤكنه \\
\hline 3 & 2895 & 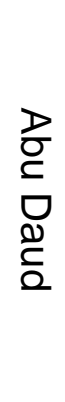 & $\begin{array}{l}\text { Orang } \\
\text { yang } \\
\text { makan } \\
\text { riba dan } \\
\text { orang } \\
\text { yang } \\
\text { memberik } \\
\text { annya }\end{array}$ & كله الربا \\
\hline 4 & 1127 & 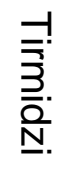 & $\begin{array}{l}\text { Makan } \\
\text { riba }\end{array}$ & \\
\hline 5 & 5013 & 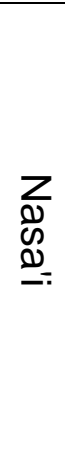 & $\begin{array}{l}\text { Mentato } \\
\text { dan } \\
\text { perbedaa } \\
\text { n pada } \\
\text { Abdullah } \\
\text { bin } \\
\text { murrah } \\
\text { dan } \\
\text { Asysya'bi }\end{array}$ & والاختر \\
\hline 6 & 5014 & 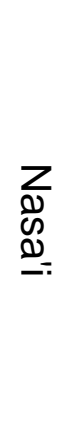 & $\begin{array}{l}\text { Mentato } \\
\text { dan } \\
\text { perbedaa } \\
\text { n pada } \\
\text { Abdullah } \\
\text { bin } \\
\text { murrah } \\
\text { dan } \\
\text { Asysya'bi }\end{array}$ & 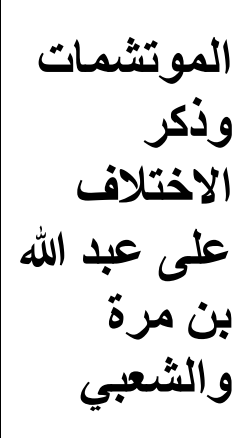 \\
\hline
\end{tabular}




\begin{tabular}{|c|c|c|c|c|c|c|c|c|c|}
\hline \multirow[t]{2}{*}{7} & \multirow[t]{2}{*}{5015} & \multirow[t]{2}{*}{ בֶ: } & \multirow{2}{*}{\begin{tabular}{|l|} 
Mentato \\
dan \\
perbedaa \\
$n \quad$ pada \\
Abdullah \\
bin \\
murrah \\
dan \\
Asysya'bi \\
\end{tabular}} & \multirow{2}{*}{ 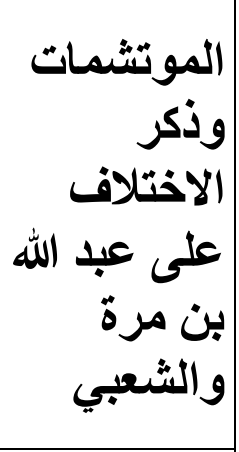 } & $\vec{\omega}$ & $\vec{N}$ & 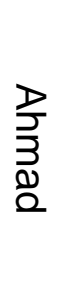 & \begin{tabular}{|l} 
Musnad \\
Ali bin \\
Abu \\
Thalib \\
Radliyalla \\
hu 'anhu
\end{tabular} & ومن مسني بن أبي \\
\hline & & & & & \multirow[b]{2}{*}{$\vec{A}$} & \multirow[b]{2}{*}{ 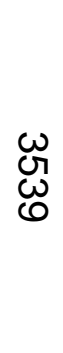 } & \multirow{2}{*}{ 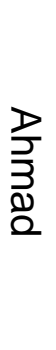 } & \multirow{2}{*}{$\begin{array}{l}\text { Musnad } \\
\text { Abdullah } \\
\text { bin } \\
\text { Mas'ud } \\
\text { Radliyalla } \\
\text { hu ta'ala } \\
\text { 'anhu }\end{array}$} & \multirow{2}{*}{ مسند عبد } \\
\hline \multirow[b]{2}{*}{8} & \multirow[b]{2}{*}{5016} & \multirow{2}{*}{ 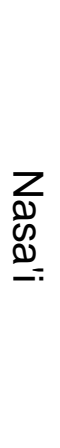 } & \multirow{2}{*}{\begin{tabular}{|l|} 
Mentato \\
dan \\
perbedaa \\
$n \quad$ pada \\
Abdullah \\
bin \\
murrah \\
dan \\
Asysya'bi
\end{tabular}} & \multirow{2}{*}{ 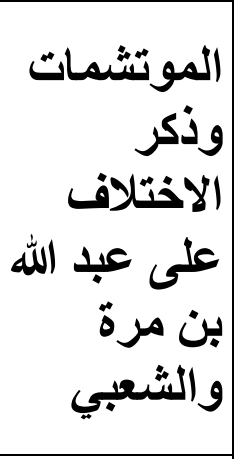 } & & & & & \\
\hline & & & & & \multirow[t]{2}{*}{$\vec{G}$} & \multirow[t]{2}{*}{$\begin{array}{l}\text { U్ } \\
\text { ज్ర }\end{array}$} & \multirow[t]{2}{*}{ 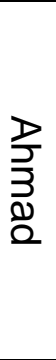 } & \multirow{2}{*}{$\begin{array}{l}\text { Musnad } \\
\text { Abdullah } \\
\text { bin } \\
\text { Mas'ud } \\
\text { Radliyalla } \\
\text { hu ta'ala } \\
\text { 'anhu }\end{array}$} & \multirow{2}{*}{ مسند عبد } \\
\hline \multirow[b]{2}{*}{9} & \multirow[b]{2}{*}{2268} & \multirow{2}{*}{ 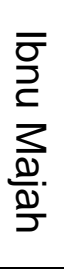 } & \multirow{2}{*}{$\begin{array}{l}\text { Teguran } \\
\text { keras } \\
\text { dalam riba }\end{array}$} & \multirow{2}{*}{ التخليظ في } & & & & & \\
\hline & & & & & \multirow[b]{2}{*}{$\vec{\sigma}$} & \multirow[b]{2}{*}{$\frac{\omega}{\infty}$} & \multirow{2}{*}{ 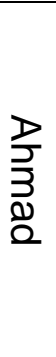 } & \multirow{2}{*}{$\begin{array}{l}\text { Musnad } \\
\text { Abdullah } \\
\text { bin } \\
\text { Mas'ud } \\
\text { Radliyalla } \\
\text { hu ta'ala } \\
\text { 'anhu }\end{array}$} & عبد \\
\hline \multirow[t]{2}{*}{$\overrightarrow{0}$} & \multirow[t]{2}{*}{$\stackrel{\mathscr{\omega}}{\mathscr{\omega}}$} & \multirow[t]{2}{*}{ 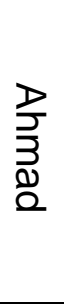 } & \multirow{2}{*}{$\begin{array}{l}\text { Musnad } \\
\text { Ali bin } \\
\text { Abu } \\
\text { Thalib } \\
\text { Radliyalla } \\
\text { hu 'anhu }\end{array}$} & \multirow{2}{*}{ ومن مسند } & & & & & ي الله \\
\hline & & & & & & & & $\begin{array}{l}\text { Musnad } \\
\text { Abdullah }\end{array}$ & \\
\hline$\vec{z}$ & 용 & $\begin{array}{l}\frac{1}{2} \\
3 \\
2 \\
2\end{array}$ & $\begin{array}{l}\text { Musnad } \\
\text { Ali bin } \\
\text { Abu } \\
\text { Thalib } \\
\text { Radliyalla }\end{array}$ & ل رضي & $\vec{v}$ & $\begin{array}{l}\omega \\
\stackrel{D}{\infty} \\
\text { v }\end{array}$ & 﨎 & $\begin{array}{l}\text { bin } \\
\text { Mas'ud } \\
\text { Radliyalla } \\
\text { hu ta'ala } \\
\text { 'anhu }\end{array}$ & حي الله عند \\
\hline & & & hu 'anhu & & & & & Musnad & \\
\hline$\vec{N}$ & $\vec{N}$ & 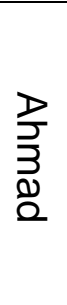 & $\begin{array}{l}\text { Musnad } \\
\text { Ali bin } \\
\text { Abu } \\
\text { Thalib } \\
\text { Radliyalla } \\
\text { hu 'anhu }\end{array}$ & ومن ملي بن أبي & $\bar{\infty}$ & 我 & 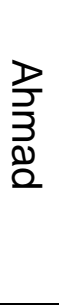 & $\begin{array}{l}\text { Abdullah } \\
\text { bin } \\
\text { Mas'ud } \\
\text { Radliyalla } \\
\text { hu ta'ala } \\
\text { 'anhu }\end{array}$ & لمود \\
\hline
\end{tabular}


Nurhadi : Mausu'ah Wa Mafhumul Hadis Larangan Transaksi Riba Dalam Musnad

\begin{tabular}{|c|c|c|c|c|}
\hline $\overrightarrow{0}$ & $\begin{array}{l}8 \\
8 \\
8\end{array}$ & 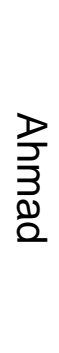 & $\begin{array}{l}\text { Musnad } \\
\text { Abdullah } \\
\text { bin } \\
\text { Mas'ud } \\
\text { Radliyalla } \\
\text { hu ta'ala } \\
\text { 'anhu }\end{array}$ & سند عبد \\
\hline No & $\frac{\vec{\theta}}{6}$ & $\begin{array}{l}\frac{7}{3} \\
3 \\
0 \\
0 \\
0\end{array}$ & $\begin{array}{l}\text { Musnad } \\
\text { Abdullah } \\
\text { bin } \\
\text { Mas'ud } \\
\text { Radliyalla } \\
\text { hu ta'ala } \\
\text { 'anhu }\end{array}$ & الله \\
\hline 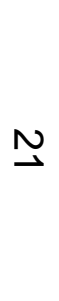 & $\begin{array}{l}\vec{\omega} \\
\stackrel{\vec{P}}{P}\end{array}$ & $\begin{array}{l}\frac{7}{2} \\
3 \\
0 \\
0 \\
2\end{array}$ & $\begin{array}{l}\text { Musnad } \\
\text { Jabir bin } \\
\text { Abdullah } \\
\text { Radliyalla } \\
\text { hu ta'ala } \\
\text { 'anhu }\end{array}$ & عابله \\
\hline N & $\stackrel{N}{N}$ & 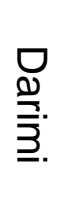 & $\begin{array}{l}\text { Pemakan } \\
\text { riba dan } \\
\text { pemberiny } \\
\text { a }\end{array}$ & مؤكله \\
\hline
\end{tabular}

Sedangkan hadis nomor 1222 dalam musnad ahmad, maka akan muncul pada Kitab: Musnad sepuluh sahabat yang dijamin masuk surga, Bab: Musnad Ali bin Abu Thalib Radliyallahu 'anhu, No. Hadist: 1222, hadişnya sebagai berikut:

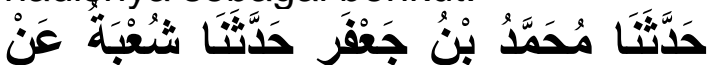

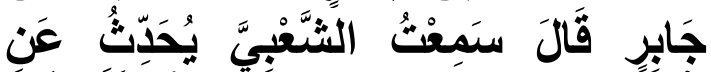

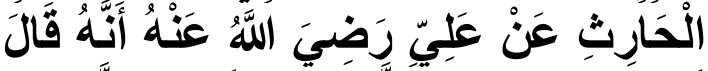

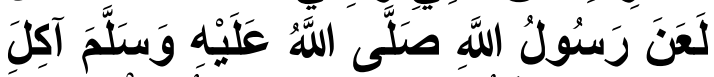

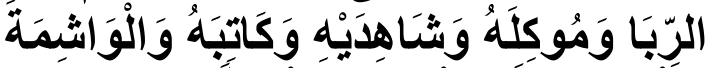

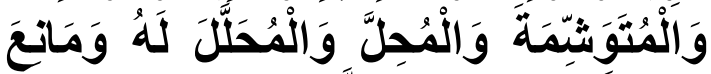

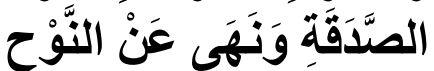

Artinya: Telah menceritakan kepada kami Muhammad bin Ja'far telah menceritakan kepada kami Syu'bah dari Jabir berkata; saya mendengar Asy Sya'bi menceritakan dari Al
Harits dari Ali Radhiallah 'anhu, dia berkata; "Rasulullah shallallahu 'alaihi wasallam melaknat orang yang memakan riba, orang yang memberi makan dengan harta riba, kedua saksinya, wanita yang mentato dan wanita yang meminta ditato, al muhallil dan al muhallal lahu, orang yang tidak mau membayar zakat, dan beliau juga melarang meratapi mayat."(HR Ahmad, t.th: No. 1222).

Hadis Ahmad No. 1122 diatas didukung dengan 19 hadis dari beberapa riwayat. Lihat tabel mausu'ah hadis kutub al-Tis'ah berikut ini:

\begin{tabular}{|c|c|c|c|c|}
\hline \multirow{2}{*}{\multicolumn{5}{|c|}{ 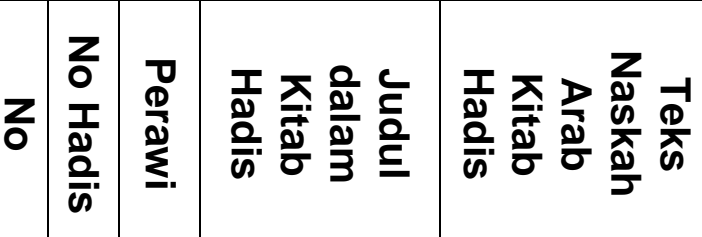 }} \\
\hline & & & & \\
\hline 1 & $\mid \begin{array}{l}0 \\
\mathbb{0} \\
\not\end{array}$ & $\frac{\frac{3}{c}}{\frac{0}{3}}$ & $\begin{array}{l}\text { Pemakan } \\
\text { riba dan } \\
\text { pemberinya } \\
\text { akan } \\
\text { dilaknat }\end{array}$ & لعونكله آكل الربا \\
\hline 2 & $\begin{array}{l}\tilde{U} \\
\mathbb{U} \\
\mathcal{T}\end{array}$ & $\frac{\frac{3}{\frac{1}{5}}}{\frac{1}{3}}$ & $\begin{array}{l}\text { Pemakan } \\
\text { riba dan } \\
\text { pemberinya } \\
\text { akan } \\
\text { dilaknat }\end{array}$ & لعن لعؤكله آلربـا \\
\hline 3 & $\begin{array}{l}0 \\
\infty \\
o \\
G\end{array}$ & 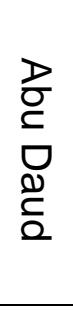 & $\begin{array}{l}\text { Orang yang } \\
\text { makan riba } \\
\text { dan orang } \\
\text { yang } \\
\text { memberika } \\
\text { nnya }\end{array}$ & في وآكل الربا \\
\hline 4 & $\vec{N}$ & $\begin{array}{l}\overline{\bar{B}} \\
\overline{\bar{z}} \\
\underline{\underline{N}}\end{array}$ & Makan riba & \\
\hline
\end{tabular}




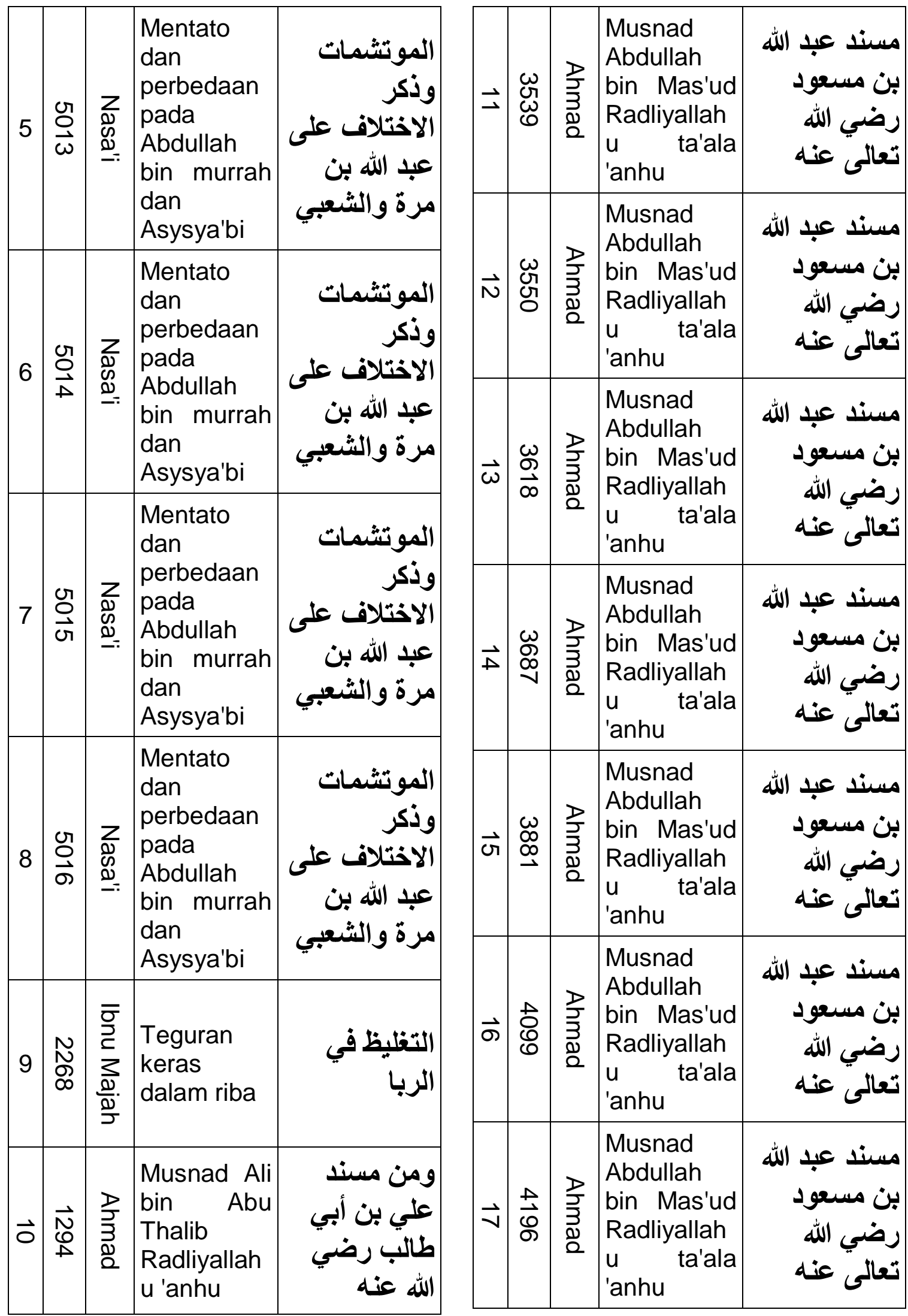


Nurhadi : Mausu'ah Wa Mafhumul Hadis Larangan Transaksi Riba Dalam Musnad

\begin{tabular}{|c|c|c|c|c|}
\hline$\infty$ & 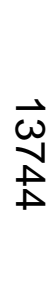 & 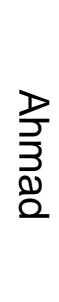 & $\begin{array}{l}\text { Musnad } \\
\text { Jabir bin } \\
\text { Abdullah } \\
\text { Radliyallah } \\
\text { u ta'ala } \\
\text { 'anhu }\end{array}$ & رضي \\
\hline 6 & $\stackrel{N}{N}$ & 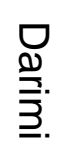 & $\begin{array}{l}\text { Pemakan } \\
\text { riba dan } \\
\text { pemberinya }\end{array}$ & \\
\hline
\end{tabular}

Sedangkan hadis nomor 1294 dalam musnad ahmad, maka akan muncul pada Kitab: Musnad sepuluh sahabat yang dijamin masuk surga, Bab: Musnad Ali bin Abu Thalib Radliyallahu 'anhu, No. Hadist: 1294, hadisnya sebagai berikut:

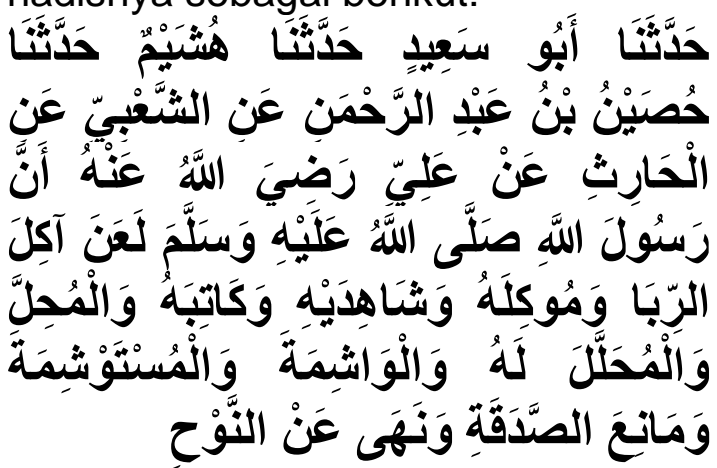

Artinya: Telah menceritakan kepada kami Abu Sa'id telah menceritakan kepada kami Husyaim telah menceritakan kepada kami Hushain bin Abdurrahman dari Asy Sya'bi dari Al Harits dari Ali Radhiallah 'anhu bahwa Rasulullah shallallahu 'alaihi wasallam melaknat orang yang memakan riba, orang yang memberi makan dengan harta riba, kedua saksinya, (dan beliau melaknat) al muhallil dan al muhallal lahu, wanita yang mentato dan wanita meminta ditato, orang yang tidak mau membayar zakat, dan beliau juga melarang meratapi mayat." (HR Ahmad, t.th: No. 1294).

Hadis Ahmad No. 1294 diatas didukung dengan 14 hadis dari beberapa riwayat. Lihat tabel mausu'ah hadis kutub al-Tis'ah berikut ini:

\begin{tabular}{|c|c|c|c|c|}
\hline$z$ & 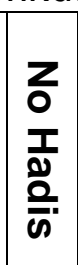 & 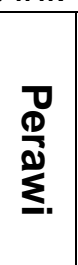 & 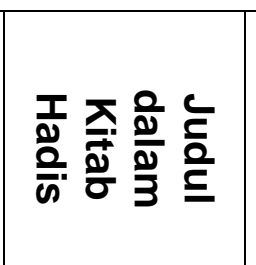 & 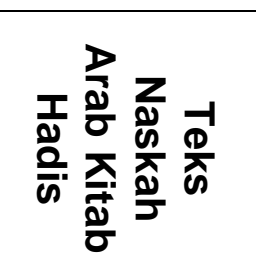 \\
\hline 1 & $\begin{array}{l}\widetilde{\Xi} \\
\mathbb{0} \\
\mathbb{1}\end{array}$ & $\begin{array}{l}\frac{3}{c} \\
\frac{1}{\infty} \\
\frac{\bar{m}}{3}\end{array}$ & \begin{tabular}{|l|} 
Pemakan \\
riba dan \\
pemberinya \\
akan \\
dilaknat
\end{tabular} & لعن آكل الربـا \\
\hline 2 & $\begin{array}{l}0 \\
\mathbb{0} \\
\text { of }\end{array}$ & $\begin{array}{l}\frac{3}{c} \\
\frac{5}{5} \\
\overline{3}\end{array}$ & $\begin{array}{l}\text { Pemakan } \\
\text { riba dan } \\
\text { pemberinya } \\
\text { akan } \\
\text { dilaknat }\end{array}$ & لعن آكل الريا \\
\hline 3 & $\begin{array}{l}0 \\
\mathbb{0} \\
c \\
\mathcal{G}\end{array}$ & 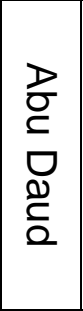 & $\begin{array}{l}\text { Orang yang } \\
\text { makan riba } \\
\text { dan orang } \\
\text { yang } \\
\text { memberika } \\
\text { nnya }\end{array}$ & في في آكل الربا \\
\hline 4 & $\overrightarrow{\vec{N}}$ & $\begin{array}{l}\overline{-} ! \\
\overline{\overline{3}} \\
\overline{\bar{n}} \\
\underline{\underline{N}}\end{array}$ & Makan riba & \\
\hline 5 & $\frac{O}{O}$ & 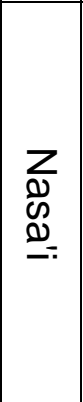 & \begin{tabular}{|l|} 
Mentato \\
dan \\
perbedaan \\
pada \\
Abdullah \\
bin murrah \\
dan \\
Asysya'bi
\end{tabular} & الاخترتلاف على اللثمات \\
\hline 6 & $\begin{array}{l}M \\
O \\
\text { G }\end{array}$ & 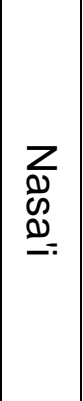 & $\begin{array}{l}\text { Mentato } \\
\text { dan } \\
\text { perbedaan } \\
\text { pada } \\
\text { Abdullah } \\
\text { bin murrah } \\
\text { dan } \\
\text { Asysya'bi }\end{array}$ & 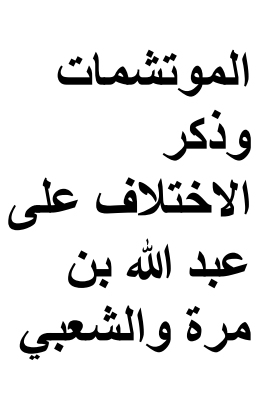 \\
\hline
\end{tabular}




\begin{tabular}{|c|c|c|c|c|}
\hline 7 & $\frac{\text { ç }}{\circ}$ & 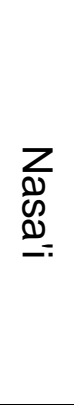 & $\begin{array}{l}\text { Mentato } \\
\text { dan } \\
\text { perbedaan } \\
\text { pada } \\
\text { Abdullah } \\
\text { bin murrah } \\
\text { dan } \\
\text { Asysya'bi }\end{array}$ & ثن بنى \\
\hline 8 & $\begin{array}{l}\text { N } \\
\text { O } \\
\infty\end{array}$ & 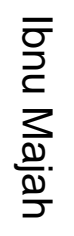 & $\begin{array}{l}\text { Teguran } \\
\text { keras } \\
\text { dalam riba }\end{array}$ & \\
\hline 9 & $\begin{array}{l}\omega \\
\mathcal{J ~} \\
\mathcal{W}\end{array}$ & 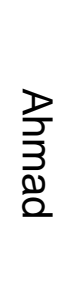 & $\begin{array}{l}\text { Musnad } \\
\text { Abdullah } \\
\text { bin Mas'ud } \\
\text { Radliyallah } \\
\text { u ta'ala } \\
\text { 'anhu }\end{array}$ & له له الله \\
\hline $\overrightarrow{0}$ & $\begin{array}{l}\omega \\
\text { J } \\
\text { ల్ }\end{array}$ & 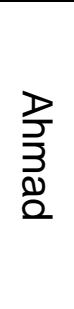 & $\begin{array}{l}\text { Musnad } \\
\text { Abdullah } \\
\text { bin Mas'ud } \\
\text { Radliyallah } \\
\text { u ta'ala } \\
\text { 'anhu }\end{array}$ & 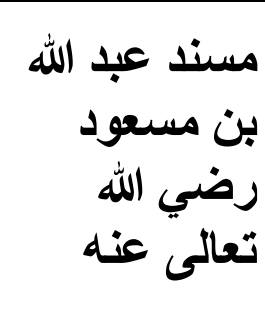 \\
\hline$\vec{z}$ & $\frac{\omega}{\infty}$ & $\begin{array}{l}\text { D } \\
3 \\
3 \\
\varrho \\
\varrho\end{array}$ & $\begin{array}{l}\text { Musnad } \\
\text { Abdullah } \\
\text { bin Mas'ud } \\
\text { Radliyallah } \\
\text { u ta'ala } \\
\text { 'anhu }\end{array}$ & 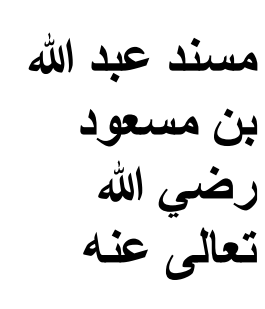 \\
\hline$\vec{N}$ & $\begin{array}{l}0 \\
8 \\
6\end{array}$ & 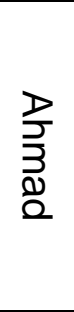 & $\begin{array}{l}\text { Musnad } \\
\text { Abdullah } \\
\text { bin Mas'ud } \\
\text { Radliyallah } \\
\text { u ta'ala } \\
\text { 'anhu }\end{array}$ & 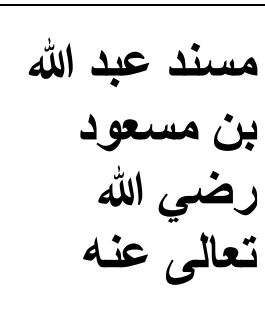 \\
\hline$\omega$ & 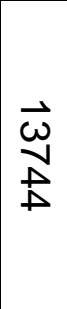 & 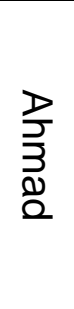 & $\begin{array}{l}\text { Musnad } \\
\text { Jabir bin } \\
\text { Abdullah } \\
\text { Radliyallah } \\
\text { u ta'ala } \\
\text { 'anhu }\end{array}$ & رضير بن \\
\hline
\end{tabular}

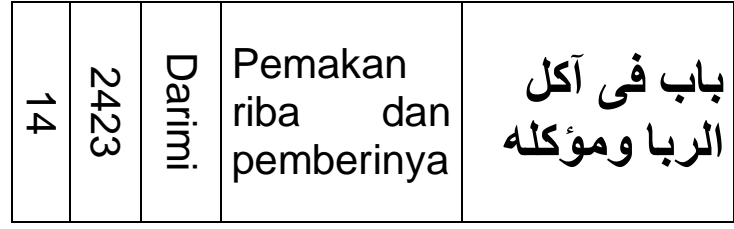

Sedangkan hadis nomor $\underline{3539}$ dalam musnad ahmad, maka akan muncul pada itab: Musnad sahabat yang banyak meriwayatkan hadits, Bab: Musnad Abdullah bin Mas'ud Radliyallahu ta'ala 'anhu, No. Hadist: 3539, hadisnya sebagai berikut:

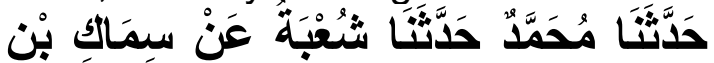

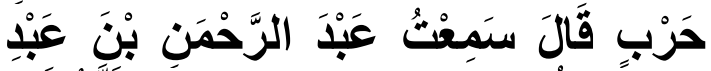

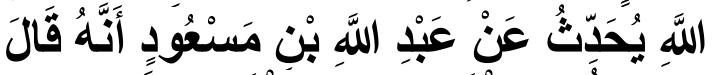

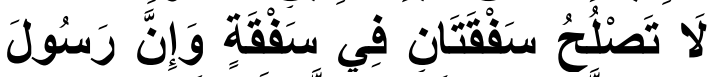

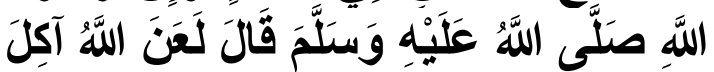

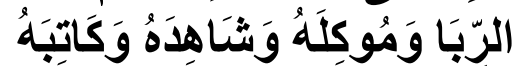

Artinya: Telah menceritakan kepada kami Muhammad telah menceritakan kepada kami Syu'bah dari Simak bin Harb ia berkata; Aku mendengar Abdurrahman bin Abdullah menceritakan dari Abdullah bin Mas'ud bahwa ia berkata; Tidak sah ada dua akad (jual beli) dalam satu akad, sesungguhnya Rasulullah shallallahu 'alaihi wasallam bersabda: "Allah melaknat pemakan harta riba, yang memberinya, saksi atas akad riba dan orang yang menuliskannya." (HR Ahmad, t.th: No. 3539).

Hadis Ahmad No. 3539 diatas didukung dengan 17 hadis dari beberapa riwayat. Lihat tabel mausu'ah hadis kutub al-Tis'ah berikut ini:

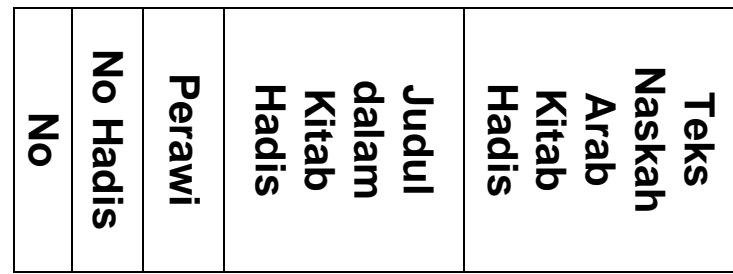


Nurhadi : Mausu'ah Wa Mafhumul Hadis Larangan Transaksi Riba Dalam Musnad Ahmad

DOI:10.24014/af.v18.i1.6705

\begin{tabular}{|c|c|c|c|c|c|c|c|c|c|}
\hline 1 & $\begin{array}{l}0 \\
\varnothing \\
\varnothing \\
f\end{array}$ & $\frac{3}{\frac{3}{\frac{5}{5}}}$ & \begin{tabular}{|l|}
\multicolumn{2}{|l|}{ Pemakan } \\
riba dan \\
pemberinya \\
akan \\
dilaknat
\end{tabular} & ومؤكله آكل الربا & \multirow[t]{2}{*}{8} & \multirow[t]{2}{*}{$\begin{array}{l}G \\
O \\
\sigma\end{array}$} & \multirow[t]{2}{*}{ 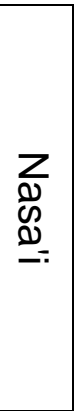 } & \multirow{2}{*}{\begin{tabular}{|l|} 
Mentato \\
dan \\
perbedaan \\
pada \\
Abdullah \\
bin murrah \\
dan \\
Asysya'bi \\
\end{tabular}} & \multirow{2}{*}{ الاختّلاف على على اللثمات } \\
\hline \multirow{2}{*}{2} & \multirow{2}{*}{$\begin{array}{l}0 \\
\mathbb{E} \\
o\end{array}$} & \multirow{2}{*}{$\frac{3}{\frac{3}{c}}$} & \multirow{2}{*}{$\begin{array}{l}\text { Pemakan } \\
\text { riba dan } \\
\text { pemberinya } \\
\text { akan } \\
\text { dilaknat }\end{array}$} & \multirow{2}{*}{ لعن آكل الربا } & & & & & \\
\hline & & & & & \multirow[b]{2}{*}{9} & \multirow{2}{*}{$\begin{array}{l}N \\
\mathbb{\infty} \\
\infty\end{array}$} & \multirow{2}{*}{ 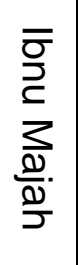 } & \multirow{2}{*}{$\begin{array}{l}\text { Teguran } \\
\text { keras } \\
\text { dalam riba }\end{array}$} & \multirow{2}{*}{ التربانيظ في } \\
\hline \multirow{2}{*}{$\begin{array}{lll}3 & \substack{0 \\
c}\end{array}$} & \multirow{2}{*}{\multicolumn{2}{|c|}{ 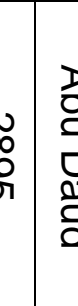 }} & \multirow{2}{*}{\begin{tabular}{|l|} 
Orang yang \\
makan riba \\
dan orang \\
yang \\
memberika \\
nnya
\end{tabular}} & \multirow{2}{*}{ ومي آكل الربا } & & & & & \\
\hline & & & & & \multirow{2}{*}{$\overrightarrow{0}$} & \multirow{2}{*}{$\begin{array}{l}\omega \\
\widetilde{N} \\
\text {, }\end{array}$} & \multirow{2}{*}{ 20 } & \multirow{2}{*}{\begin{tabular}{|l|} 
Musnad \\
Abdullah \\
bin Mas'ud \\
Radliyallah \\
u ta'ala \\
'anhu
\end{tabular}} & كود كبد الله \\
\hline \multirow[t]{2}{*}{4} & \multirow[t]{2}{*}{$\overrightarrow{\vec{N}}$} & 홀. & \multirow[t]{2}{*}{ Makan riba } & \multirow[t]{2}{*}{ أكل الرباء في } & & & & & \\
\hline & & & & & \multirow{2}{*}{\multicolumn{2}{|c|}{$د \frac{\omega}{\mathscr{M}}$}} & \multirow[b]{2}{*}{ 疍 } & \multirow{2}{*}{\begin{tabular}{|l|} 
Musnad \\
Abdullah \\
bin Mas'ud \\
Radliyallah \\
u ta'ala \\
'anhu
\end{tabular}} & \multirow[b]{2}{*}{ تبن مسند عبد الله } \\
\hline \multirow[t]{2}{*}{5} & \multirow[t]{2}{*}{ 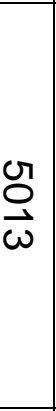 } & \multirow[t]{2}{*}{ : } & \multirow{2}{*}{\begin{tabular}{|l|} 
Mentato \\
dan \\
perbedaan \\
pada \\
Abdullah \\
bin murrah \\
dan \\
Asysya'bi \\
\end{tabular}} & \multirow{2}{*}{ |الموتشمات } & & & & & \\
\hline & & & & & \multirow{2}{*}{$\vec{N}$} & $\mathscr{\sigma}_{\infty}$ & \multirow{2}{*}{ 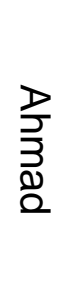 } & \begin{tabular}{|l|} 
Musnad \\
Abdullah \\
bin Mas'ud
\end{tabular} & عبد الله \\
\hline & & & $\begin{array}{l}\text { Mentato } \\
\text { dan } \\
\text { perbedaan }\end{array}$ & & & & & $\begin{array}{l}\text { Radliyallah } \\
\text { u } \quad \text { ta'ala } \\
\text { 'anhu }\end{array}$ & \\
\hline 6 & $\begin{array}{l}O \\
\\
\end{array}$ & 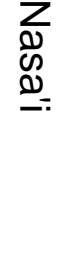 & $\begin{array}{l}\text { pada } \\
\text { Abdullah } \\
\text { bin murrah } \\
\text { dan } \\
\text { Asysya'bi }\end{array}$ & 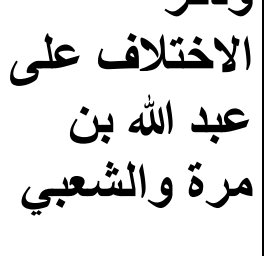 & $\vec{\omega}$ & $\mid \begin{array}{l}w \\
\infty \\
\infty \\
-1\end{array}$ & \begin{tabular}{l}
$\frac{1}{3}$ \\
\multirow{3}{2}{} \\
$\stackrel{2}{a}$
\end{tabular} & \begin{tabular}{|l|} 
Musnad \\
Abdullah \\
bin Mas'ud \\
Radliyallah \\
u ra'ala
\end{tabular} & عبد الله \\
\hline & & & & & & & & & \\
\hline 7 & $\frac{O}{v}$ & 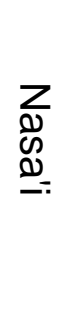 & $\begin{array}{l}\text { dan } \\
\text { perbedaan } \\
\text { pada } \\
\text { Abdullah } \\
\text { bin murrah } \\
\text { dan } \\
\text { Asysya'bi }\end{array}$ & 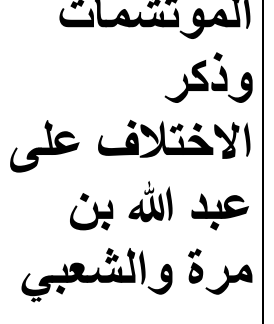 & $\vec{A}$ & $\mid \begin{array}{l}0 \\
0 \\
0\end{array}$ & 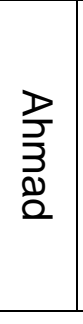 & \begin{tabular}{|l|} 
Musnad \\
Abdullah \\
bin Mas'ud \\
Radliyallah \\
u ta'ala \\
'anhu
\end{tabular} & سبود الله \\
\hline
\end{tabular}




\begin{tabular}{|c|c|c|c|c|}
\hline$\vec{G}$ & $\frac{\vec{\theta}}{6}$ & 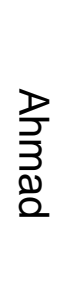 & $\begin{array}{l}\text { Musnad } \\
\text { Abdullah } \\
\text { bin Mas'ud } \\
\text { Radliyallah } \\
\text { u ta'ala } \\
\text { 'anhu }\end{array}$ & 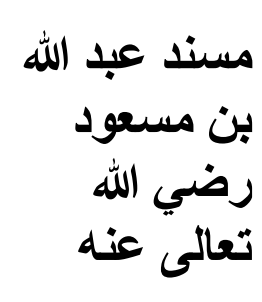 \\
\hline $\bar{\sigma}$ & $\underset{\stackrel{\vec{\omega}}{\vec{D}}}{\overrightarrow{\stackrel{D}{ }}}$ & 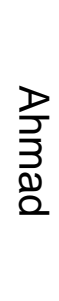 & $\begin{array}{l}\text { Musnad } \\
\text { Jabir bin } \\
\text { Abdullah } \\
\text { Radliyallah } \\
\text { u ta'ala } \\
\text { 'anhu }\end{array}$ & غني \\
\hline$\vec{v}$ & $\underset{+}{N}$ & Ð. & $\begin{array}{l}\text { Pemakan } \\
\text { riba dan } \\
\text { pemberinya }\end{array}$ & ك لd \\
\hline
\end{tabular}

Sedangkan hadis nomor 3567 dalam musnad ahmad, maka akan muncul pada Kitab: Musnad sahabat yang banyak meriwayatkan hadits, Bab: Musnad Abdullah bin Mas'ud Radliyallahu ta'ala 'anhu, No. Hadist: 3567, hadisanya sebagai berikut:

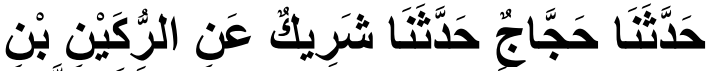

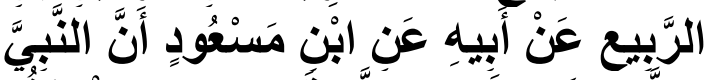

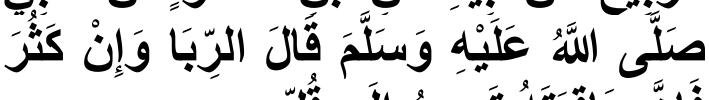

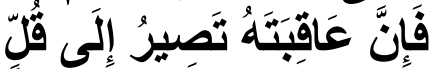

Artinya: Telah menceritakan kepada kami Hajjaj telah menceritakan kepada kami Syarik dari Ar Rukain bin Ar Rabi' dari ayahnya dari Ibnu Mas'ud bahwa Nabi shallallahu 'alaihi wasallam bersabda: "Harta riba meskipun banyak pada akhirnya akan menjadi sedikit." (HR Ahmad, t.th: No. 3567).

Hadis Ahmad No. 3567 diatas didukung dengan 1 hadis dari beberapa riwayat. Lihat tabel mausu'ah hadis kutub al-Tis'ah berikut ini:

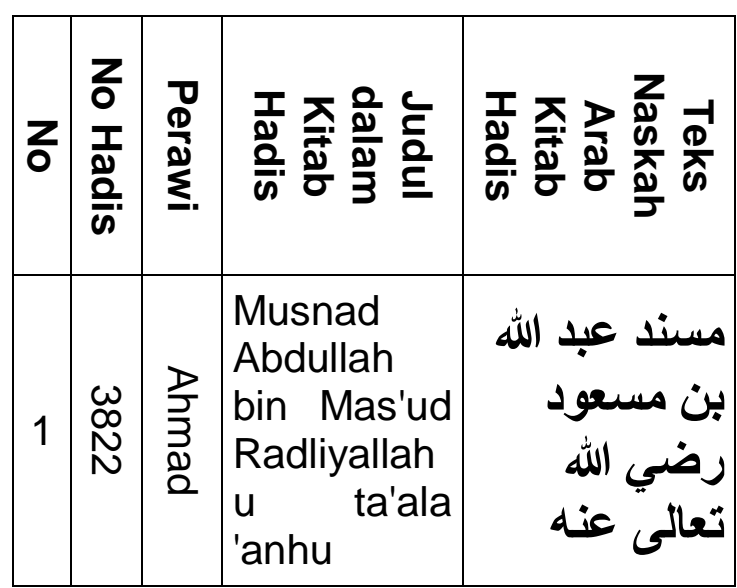

Sedangkan hadis nomor 13744 dalam musnad ahmad, maka akan muncul pada Kitab: Sisa Musnad sahabat yang banyak meriwayatkan hadits, Bab: Musnad Jabir bin Abdullah Radliyallahu ta'ala 'anhu, No. Hadist: 13744, hadisnya sebagai berikut:

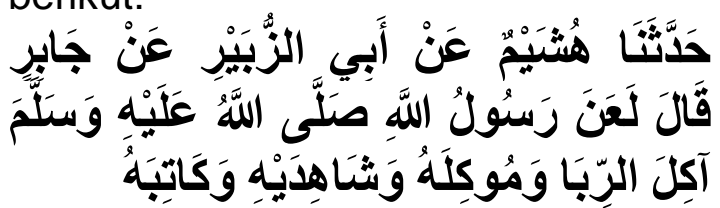

Artinya: Telah menceritakan kepada kami Husyaim dari Abu Az Zubair dari Jabir berkata; Rasulullah shallallahu 'alaihi wasallam melaknat orang yang memakan riba, yang memberi makan dengan harta riba, dua saksinya dan penulisnya (HR Ahmad, t.th: No. 13744).

Hadis Ahmad No. 13744 diatas tidak ada hadis dalam kutub al-Tis'ah yang mendukungnya.

\section{KESIMPULAN}

Hasil penelitian dapat disimpulkan bahwa dalam kitab mausu'ah al-hadis al-Nabawiyah, dari persepktif musnad Ahmaf, maka hadis yang berkaitan dengan harta riba, penulis temukan ada 6 hadis dari riwayat ahmad. Adapun hadisnya adalah hadis nomor 803 dalam kitab musnad ahmad, maka akan muncul pada Kitab: Musnad sepuluh sahabat 
yang dijamin masuk surga, Bab: Musnad Ali bin Abu Thalib Radliyallahu 'anhu, No. Hadist: 803, hadis tersebut didukung dengan 22 hadis dari beberapa riwayat. Sedangkan hadis nomor 1222 dalam musnad ahmad, maka akan muncul pada Kitab: Musnad sepuluh sahabat yang dijamin masuk surga, Bab: Musnad Ali bin Abu Thalib Radliyallahu 'anhu, No. Hadist: 1222, hadis tersebut didukung dengan 19 hadis dari beberapa riwayat. Sedangkan hadis nomor 1294 dalam musnad ahmad, maka akan muncul pada Kitab: Musnad sepuluh sahabat yang dijamin masuk surga, Bab: Musnad Ali bin Abu Thalib Radliyallahu 'anhu, No. Hadist: 1294, hadis tersebut didukung dengan 14 hadis dari beberapa riwayat. Sedangkan hadis nomor 3539 dalam musnad ahmad, maka akan muncul pada itab: Musnad sahabat yang banyak meriwayatkan hadits, Bab: Musnad Abdullah bin Mas'ud Radliyallahu ta'ala 'anhu, No. Hadist: 3539, hadis tersebut didukung dengan 17 hadis dari beberapa riwayat. Sedangkan hadis nomor 3567 dalam musnad ahmad, maka akan muncul pada Kitab: Musnad sahabat yang banyak meriwayatkan hadits, Bab: Musnad Abdullah bin Mas'ud Radliyallahu ta'ala 'anhu, No. Hadist: 3567, hadis tersebut didukung dengan 1 hadis dari beberapa riwayat. Sedangkan hadis nomor 13744 dalam musnad ahmad, maka akan muncul pada Kitab: Sisa Musnad sahabat yang banyak meriwayatkan hadits, Bab: Musnad Jabir bin Abdullah Radliyallahu ta'ala 'anhu, No. Hadist: 13744, hadis tersebut tidak ada hadis dalam kutub al-Tis'ah yang mendukungnya. Maka dari hadis tersebut dapat ditarik pemahaman bahwa Allah melaknat pemakan harta riba, orang yang memberi makan dengan harta riba, saksi atas akad riba dan orang yang menuliskannya. Harta riba meskipun banyak pada akhirnya akan menjadi sedikit.

\section{DAFTAR PUSTAKA}

Abdullah al-Mushlih dan Shalah ashShawi, Fikih Ekonomi Keuangan Islam (Jakarta: Darul Haq, 2014)

Abdullah Malik ibn Anas ibn Malik ibn Abi Amir ibn Amr ibn al-Haris ibn Gaiman ibn Husail ibn Amr ibn al-Haris al-Asbahi al-Madani, (t.th), Al-Mua'tha' Imam Malik (Beirut: Dar Fikri)

Abdurrahman al-Jaziri, Kitab al-fiqh 'ala al-Mazahib al-Arba'ah, (Beirut: dar al-Fikr, 2012)

Abdurrahman ibn 'Abdirahman ibn alFadhl ibn Bahram ibn 'Abdis Shamad, (t.th), Al-Sunan AlDarimi (Kairo Mesir: Maktabah alamiyah)

Abu 'Abdillah Muhammad bin Yazid bin 'Abdillah bin Majah alQazwini, (t.th), Al-Sunan Ibnu Majah (Mesir: Maktabah alSunnah)

Abu 'Abdirrahman ahmad bin su'aib bin ali bin bahr bin sinan bin dinar an-Nasai al-Kurasani, (t.th), Al-Sunan al-Nasa'i (Cairo: Dar IImi)

Abu 'Isa muhammad bin 'isa bin surrah al-Turmudzi Ibn Musa Ibn Adh-Dhahak Al-Sulami Al-Bughi Al-Tirmidzi, Al-Sunan Al-Tirmizi (Lebanon: Dar al-Hadis, t.th)

Abu Abdullah Muhammad bin Ismail Al-Bukhari bin Ibrahim bin AlMughirah bin Bardizbah, Imam al-Bukhari, Sahih Bukhari (Bairut: Darul Ibnu Katsir alYammah, t.th)

Abu Sura'i Abdul Hadi, Bunga Bank Dalam Islam, alih bahasa M. 
Thalib, (Surabaya: al-lkhlas, 2013)

Abu Zuhry dan Ahmad Sabiq, Hukum Jual Beli Kredit, lihat di wibesite online dalam https://abuzuhriy.wordpress.com /2010/10/03/hukum-jual-belikredit/diakses tanggal 21 september, 2018

Abul Husain Muslim bin al-Hajjaj alNaisaburi, Imam Muslim, Shahih Muslim (Beirut: Dar Ibnu Katsir, t.th)

Ahmad bin Muhammad ibn Hanbal alSyaibany, Al-Musnad Ibnu alHambali (Lebanon: Dar al-Hadis, t.th)

Ahmad Munawir, Kamus al-Munawir Arab-Indonesia, (Yogyakarta: PP. al-Munawwir, 2013)

Boy Syamsul Bakhri, Sistem Ekonomi Islam dalam Perbandingan (Jurnal Al-hikmah Vol. 8, No. 1, April, 2011, ISSN 1412-5382)

Bungin Burhan, Metodologi Penelitian Kualitatif, (Jakarta: Raja Grafindo Persada, 2014)

Chairuman Pasaribu dan Suhrawardi K. Lubis, Hukum Perjanjian Dalam Islam, (Jakarta: Sinar Grafika, 2014)

Dedy Mulyana, Metodologi Penelitian Kualitatif, (Bandung: Remaja Rosdakarya, 2015)

Departemen Agama RI, Al-Qur'an dan Terjemahanya (Semarang: Toha Putra, 2015).

Endang Soetari, IImu Hadis Kajian Riwayat dan Dirayah (Bandung: CV. Mimbar Pustaka, 2017)

Hadari Nawawi, Metode Penelitian Bidang Sosial, (Yogyakarta: Gajah Mada University Press, 2016)

Hamidi, Metode penelitian kualitatif, (Malang: Universitas Muhammadiyah Malang, 2014)
HB Sutopo, Pengantar Penelitian Kualitatif, (Surakarta: Universitas Sebelas Maret Press, 2014)

Imam Suprayogo dan Tobroni, Metodologi Penelitian SosialAgama, (Bandung: Remaja Rosdakarya, 2012)

Iskandar, Metode Penelitian Kualitatif : Aplikasi untuk Penelitian Pendidikan, Hukum, Ekonomi \& Manajemen, Sosial, Humaniora, Politik, Agama dan Filsafat, (Jakarta: Gaung Persada, 2010)

Khoiruddin Nasution, Riba dan Poligami, Sebuah Studi atas Pemikiran Muhammad Abduh, (Yogyakarta: Pustaka Pelajar bekerjasama dengan ACAdeMIA, 2016)

Lexy J Moleong, Metodologi Penelitian Kualitatif, (Bandung: Remaja Rosdakarya, 2011)

M Alawi al-Maliki, IImu Ushul Hadits (Yogyakarta: Pustaka Pelajar Offset, 2012)

M. Abdurrahman, Studi Kitab Hadis (Yogyakarta: Teras, 2013)

M. Agus Shalahudin, Ulumul Hadis (Bandung,:CV Pustaka Setia, 2013)

Muhammad A'jal Al-khatib, Pokokpokok IImu Hadis, (Jakarta: Gaya media pratama, 2014)

Muhammad Nazir, Metodologi Penelitian, (Jakata: Ghalia Indonesia, 2015)

Muslim, Tinjauan Syariat Terhadap Jual-Beli Kredit, lihat di wibesite online

https://muslim.or.id/20961-

tinjauan-syariat-terhadap-jual-

beli-kredit.html.diakses tanggal 20 september, 2018

Nawir Yuslem, Kitab Induk Hadis (Jakarta: Hijir Pustaka Utama, 2016) 
Nurhadi : Mausu'ah Wa Mafhumul Hadis Larangan Transaksi Riba Dalam Musnad Ahmad

Noeng Muhajir, Metodologi Penelitian Kualitatif, (Yogyakarta: Rake Sarasin, 2014)

Nurhadi, Analisis Hukum Perikatan Klausul Akad Pembiayaan Murabahah Bil Wakalah Nomor.090/Mrbh/Pkb/V/2016 Bank Rakyat Indonesia Syari'ah (Tesis: Program Magister (S2) Program Pascasarjana Universitas Islam Riau Pekanbaru, 2016)

Nurhadi, Hilah Syariah Kredit Bank Konvesional (Maqashid Jual Beli Kredit (Lain Kontrak Lain Akad)), Jurnal Hukum Islam, Vol XVII No. 2 Desember, 2017

Subhi al-Shalih, Membahas IImu IImu Hadis, (Jakarta: pustaka firdaus, 2017)

Syaikh Abul A'la al-Maududi, Bicara Tentang Bunga Bank dan Riba (Jakarta: Mega Media, 2014) 